\title{
Mystery and multiculturalism: Should the musterion of Ephesians 3 encourage multiculturalism in South African churches?
}

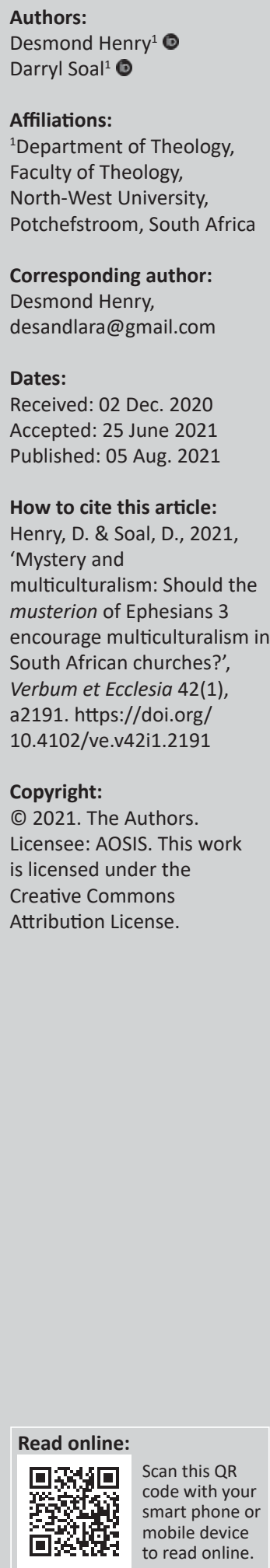

The objective was the examination of the musterion of Ephesians 3, whether it encouraged multiculturalism in South African churches. The knowledge gap was to find further biblical direction for churches experiencing cultural transitions and demographic changes. The research method was a qualitative analysis of biblical texts, as applied specifically in a South African setting, with global implications. The significance would be the cultural transitions of churches from homogeneous, local churches into culturally heterogeneous, local churches. Further questioning the homogeneous unit principle (HUP) in the light of Scripture, especially Ephesians. The results found that the musterion in Ephesians 3 pointed to the Holy Spirit's original intension for multicultural local churches. This mystery was found to be the witness of the church in this world and cosmically, to allay fear and prejudice. Further research is recommended into addressing the fears of globalisation in local churches. The contextual context affected local churches in post-Apartheid South Africa and many local churches around the world experiencing globalisation. These findings affect possible blind spots in theological studies in the New Testament, cross-cultural care in Practical Theology, Missiological findings for church growth and church planting, along with sociological findings in multiculturalism.

Intradisciplinary and/or interdisciplinary implications: The article deals with concerns for New Testament, missiology and practical theology. It challenges the homogenous unit principle in the light of Pauline discourse and synthesises research to form a contextual response to the need for multiculturalism in South African churches.

Keywords: mystery; multicultural; multiculturalism; missiology; culture; globalism; local churches.

\section{Introduction}

The social value of heterogeneous multicultural churches rests in its witness to a watching world (Jn 13:35) of unity in diversity, rather than polarisation. As the 'global village' increasingly integrates into the local church, some cultures are tempted to absent themselves. The aim is to give guidance to churches undergoing demographic changes. These cultural changes would be from 'homogeneous local churches toward culturally heterogeneous local churches' (Soal 2020:5). The objective is to find further Biblical support to question the homogeneous unit principle (HUP) (cf. Critique for HUP - Pickett 2015; cf. against HUP Plueddemann 1995; cf. see convener - Stott 1978:1). René Padilla's (1992:24-30) critique, among others, assists in ending the pragmatism of the HUP as a 'tenet of the Church Growth Movement' (Soal 2020:56).

The possibility of heterogeneous multicultural churches arises as tongues in Acts have been possited as a reversal of Babel (Soal \& Henry 2018). The concern in purely addressing the clarion call for heterogeneous multicultural churches from the book of Acts as a canon of historical persuasiveness' is that observations may be dismissed as historical and particular to that context and time (Silva 1986:131). This article seeks to expand on the findings in Acts from the Epistles, with an emphasis on Ephesians. The didactic teaching of the Epistles frequently carries greater authority in comparison to the narrative and historical portions of Scripture (Mickelson 1963:339). Progressive revelation from Acts to the Epistles becomes apparent 'if the interpreter understands the nature of the Biblical idea of progress' (Mickelson 1963:339). Ephesians demonstrates statements about multiculturalism, regarding God's mystery now revealed, 'as His will for the church' (Soal 2020:63). 
The focus of exploration will be Ephesians 3:1-13. Ephesians 2 recounts the Ephesians' status that has been transformed by the life, death and resurrection of Christ. In Ephesians 3, the writer shifts from an account of the Ephesians' situation to an account of his own status. Although Paul is the focus of the discussion in 3:1-7 and 8-13, Ephesians 3 is a discussion of the grace of God and Paul's relationship to grace.

Some commentators view Ephesians 3:1-7 as a digression. Lincoln (1990:171) posits this as a digressio in the formal rhetorical sense. Best (2001:293) counters that this section is insufficiently organised to count as a formal digressio, but proposes the passage as a digression in the 'colloquial sense' of the term (Best 2001:293). Modern commentators 'treat this passage as only indirectly relevant and not logically necessary in the light of what precedes and what follows' (Fowl 2012:103). As Paul addresses the fact that he is a prisoner in 3:13, this implies that '3:2-12 seems more like conceptual wandering than a digression' (Fowl 2012:114). Barth views Ephesians 3:2-13 as commentary on Ephesians 3:1, 'but they are more a digression than a commentary' (Barth 1974:359; Snodgrass 1996:158).

The conceptual framework uses a qualitative analysis. This article uses 'constructivism, whereby reality has been constructed, so there may be multiple interpretations. This is sometimes referred to as interpretivism' (Soal 2020:4). There will also be some elements of subjectivism, where reality is what is perceived to be reality (Pilkington \& Pretorius 2015). The theoretical assumptions use a hermeneutic approach where reality will need to be interpreted. The research fits into the subject field of theology and missiology by using the missiological findings applied in a multicultural urban local church context (Amodio et al. 2007; Gallagher 2001; Hampden-Turner \& Trompenaars 2000; Livermore 2009). The research hopes to contribute to the subject fields of missions, ecclesiology (church planting, church growth) and practical theology, by exploring 'the effects of transitions from culturally homogeneous, local churches into culturally heterogeneous, local churches' (Soal 2020:3).

\section{Authorship}

The issue of the authorship of Ephesians should be examined as it affects the authority of the findings of this mystery in Ephesian 3. Commentators who propose a later author, question the theological propositions of the Epistle and thus doubt whether this mystery is significant. Pauline authorship also affects the pastoral perspective. If Paul, who persecuted the church when he was Saul of Tarsus, can 'be transformed from murderous hatred, then' there are possibilities for perjudices among church member in the 21st century (Soal 2020:64).

The text in Ephesians ascribes authorship of Ephesians to the Apostle Paul. Some critics of the New Testament affirm that the words 'I, Paul ...' (Eph 3:1) 'were forged to this epistle by some later author' (Coffman 1999:1). Among these commentators, the approach examines differences between different Pauline writings and then argues that Ephesians was not Pauline, but written by 'an imitating disciple' after his death (Lincoln 1990:168). The ethical implications of pseudonymity in Ephesians 3 are 'at best premature and misconceived, and so must be rejected' (Asumang 2009:6). We are 'well advised to avoid making overhasty judgments in this regard' (Fowl 2012:104). The sheltering theory of a 'Pauline façade' may be disposed of by retaining the Epistle's claims to be written by 'I, Paul' - the apostle Paul himself (Asumang 2009:6). After analysis of authors for and against Pauline authorship, using a statistical model, the evidence seems to tilt in Paul's favour, which means the 'support for Pauline authorship of Ephesians should not be easily dismissed' (Hoehner 2002:124). Pauline authorship will be assumed for this article into the mystery in Ephesians.

\section{Mysterion}

'Mystery is met in Ephesians' (Soal 2020:65). A mystery is something that is hidden, inexplicable or unknown. The Greek $\mu v \sigma \tau$ ípıov (mysterion from myein) means 'to shut' or 'to close' (Strong 2001:49). In Ephesians, Paul refers to three 'mysteries'. Firstly, the mystery of his will in the fulness of times (Eph 1:9-10), then, secondly, the Gentiles becoming fellow heirs in Christ through the gospel (Eph 3:3-6) and thirdly, the mystery of marital living and the church's 'marriage' to Christ (Eph 5:31-32).

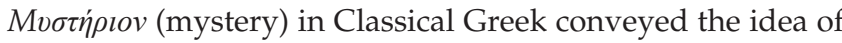
silence during the rites of the 'mystery' religions in the Greco-

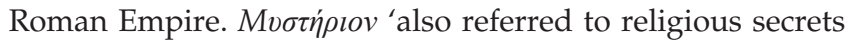
which were confided to the initiated' (Soal 2020:65). NT usage of $\mu v \sigma \tau$ ' $\rho \imath v$ was not only unintelligible, nor mysterious (as in a Sherlock Holmes 'mystery') but was also God's secret until he chose to reveal it through Paul to all who read Ephesians. Wiersbe (1989) writes that, in the NT:

A mystery is not something eerie or inscrutable, but rather a truth that was hidden by God in times past and is now revealed to those who are in His family. (p. 80)

A mystery is a sacred secret, not known to unbelievers, but understood by the people of God.

The self-reference, 'I, Paul', is used on six occasions. In two (2 Cor 10:1, Gl 5:2), 'I, Paul' precedes an authoritative statement. In 1 Thessalonians 2:18, it is used to single Paul out from among his team members in a personal matter. And in Philemon 1:19, Paul uses the phrase to do both. In the remaining two instances (Col 1:23, Eph 3:1), 'the self-reference is used to describe his mission as a receiver and proclaimer of God's mystery' (Asumang 2009:10). It is this receipt of revelation of Divine origin, which gives the emphasis to the implications of the meaning of 'mystery'. This means that, 'Ephesians 3 is an important prism through which to interpret the whole epistle' (Asumang 2009:22). The importance of this prism for multicultural arguments for the local church needs emphasis to help churches in transitioning to multiculturalism. 
Daniel in the OT holds keys to understanding the use of the phrase 'I, Paul'. Daniel uses an unusually similar selfreference to associate the reception of God's revelation. Paul follows Daniel's pattern. On seven occasions, Daniel uses the phrase 'I, Daniel' (Dn 7:5; 8:15, 27; 9:2; 10:2, 7; 12:5). 'In all of them, the self-reference is used to report the reception of revelation' (Asumang 2009:11).

The mystery now revealed in Ephesians 3 proceeds from comments concerning a believer's unity with God the father through faith in Jesus Christ (Eph 1). Ephesians 3 also follows chapter 2 dealing with the unity of Jews and Gentiles, where the two become one new man and new body (Eph 2:16, 19). Paul intends to pray for the Ephesians (Eph 3:1, 14-19). However, in Ephesians 3:2-13, he 'interrupts himself in this digression', to remind the readers of his apostolic mission (Soal 2020:66).

Paul used $\mu v \sigma \tau$ f́ meanings (Howard 1979:3). In Colossians (1:26-27; 2:2; 4:3), $\mu v \sigma \tau$ prov means God's redemptive purpose in Christ to save sinners, whereas in Ephesians, $\mu v \sigma \tau \eta \dot{p} \rho \imath$ v is used in a broader sense to mean the reconciliation of 'all things in Christ' (Eph 1:9-10) and the $\mu v \sigma \tau \eta \dot{\rho} \rho \imath v$ is God's purpose to bring both Jews and Gentiles together in the 'same body' (Eph 3:3-6).

\section{A mystery revealed (Eph 3:1-3)}

Paul reveals a mystery. Paul ambiguiously links his incarceration as a prisoner of Christ to it being on behalf of 'you Gentiles' (Eph 3:1). It reflects the concept that Paul is a prisoner because of Christ. In another sense, being a prisoner of Christ illuminates the idea that Christ has captured Paul. 'Having had the mystery of God's saving purposes revealed to him, Paul is now compelled to preach the gospel' (Fowl 2012:106). Paul is Christ's prisoner. The implication is that if he had remained a 'Jewish Christian with a mission to Jews or if he had been willing to keep Gentiles on a lower plane, he would not have been in jail' (Snodgrass 1996:159). Paul's apostolic activity rests on the recognition by the Ephesians of their Gentile identity, to empower them to understand themselves properly before God.

The word Gentiles (ethnos); ( $\tau \tilde{\omega} v \dot{\varepsilon} \theta v \tilde{\omega} v$ in Eph 3:1) refers to non-Jews or the heathen. The definite article ('the') before ethnos in the Greek means 'the nations'. The Gentiles were thus marked out as a distinct class, who practice idolatry and are ignorant of the true God. Usually, by implication, they are pagan (Strong 2001:25).

Jewish charges led to Paul's arrest (Ac 21:27), yet he did not refer himself as a prisoner of the Jews. Paul was imprisoned by Roman authorities (Ac 21:33), yet he did not view himself a prisoner of Rome. Although he appealed to Caesar (Ac 25:11), he did not consider himself Caesar's prisoner. He was a bond-slave of Jesus Christ, 'given the special mission of preaching the gospel to the Gentiles' (MacArthur 1986:87).

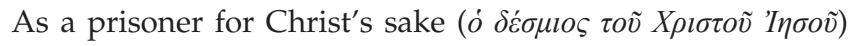
'has been called a genitive of originating cause, to identify
Paul as a prisoner belonging to Jesus Christ, who was the cause of his imprisonment' (MacArthur 1986:86).

Paul's assertion that he has been made a steward (oikovoríav) of the grace of God meant that his activity within 'the drama of salvation are initiated and sustained by God (rather than Paul's own initiative)' (Soal 2020:67). Paul plays this role of steward for the sake of the Gentiles (Best 2001:299). A steward primarily managed a household, business or other concern on behalf of 'someone else' (MacArthur 1986:89). Paul the steward, takes care of God's grace. The Gentiles will be deprived of God's grace, if he fails in his task as a steward, and 'the multicultural church would simply be a cultural ideal rather than a Biblical imperative' (Soal 2020:68).

Paul addresses a multicultural church in Ephesus. 'Both Jewish and Gentile converts made up the local church. The church at Ephesus was thus multicultural or multi-ethnic (Ac 19:8-17; 20:21)' (Soal 2020:68). As the ethnically, multicoloured (manifold) congregations in Ephesus read Paul's letter, they learned that the church is composed of a variety or 'multi-coloured (manifold) people' (Gray 2013:1). 'Biblical evidence does not support the notion of a homogeneous church at Ephesus' (Soal 2020:68).

Paul's theme for the Ephesians can be stated as follows: 'the unity of the church for the sake of the Gospel' (DeYmaz 2013:1). 'The mystery revealed through Paul to a multicultural church is unity between all the diverse cultures in the church' (Soal 2020:68).

\section{A different mystery (Eph 3:4)}

Is the 'mystery' Paul is addressing (in Eph 3:4) the mystery of the gospel? The mystery of the gospel is the Good News message of Christ's life, death, resurrection and atonement for $\sin$. The Good News received by faith is the means by which people of all cultures might be saved (Eph 2:8). Yet, Ephesians 3:6 clarifies that the mystery of Christ is something rather different: 'This mystery is that through the gospel the Gentiles are heirs together with Israel, members together of one body, and sharers together in the promise in Christ Jesus' (Eph 3:6).

Fierce has been the debate around the definition of mystery in Ephesians. 'Mystery here is defined differently from its definition in Colossians, leading to the assertion that the difference is so great as to make common authorship impossible' (Foulkes 1963:93). Foulkes (1963:93) rejects this simplistic understanding of the mystery, asking, ' $[c]$ an they not be different aspects of the central revelation?' The likelihood of different aspects of revelation may be the complex and interlocking elements of mystery (Coffman 1999:3). 'The Mystery of Christ includes far more than the fact that Gentiles were fellow partakers with Jews of the promise in Christ Jesus' (Lipscomb 1939:57). A full discussion of the mystery of redemption has been attempted by Coffman (Coffman 1976, 1999). 
Paul's reasoning for multicultural local churches whenever possible are manifold. The obvious reason, seen above, is soteriological, for Christ 'who has made us both one' to 'reconcile us both to God' (Eph 2:14-16, 19, 21-22). Another reason is Christological and missiological, as 'this mystery is that the Gentiles are ... partakers of the promise in Christ Jesus through the gospel' (Eph 3:6). A third reason was the gospel of God's grace, which caused people to love Christ, which, in turn, should lead to a love of 'each other in such away they formed "one new man", in spite of the 1st century Greco-Roman culture that said they should hate each other' (Gray 2013:2). An eschatological reason (Rv 7:9-12) would mean that the eternal gathered together people (church) will be multicultural. There will be no separate 'white church, black church, Latino church, or Asian church' (Gray 2013:3). Eschatologically, there will be 'the inclusion of the Gentiles in a multiracial church where ethnic and religious barriers are transcended' (Martin 1991:41).

Theologically, Ephesians links divine revelation to mystery. Precedent for this theology is found in the Old Testament concept of the revelation of the secrets of the Divine Council (Brown 1958:417-433). OT prophets experienced 'God's gracious act of allowing a human being to share in the secrets of His Council' (e.g. Jr 23:18, Am 3:7, Is 6:8); (Asumang 2009:13). 'The NT term $\mu v \sigma \tau$ ń unknown' (Soal 2020:69). 'Rather, in a Semitic context it refers to what is known only because God revealed it' (Snodgrass 1996:159). 'In Ephesians 3:1-13 it refers to the revelation that the Gentiles are included as equals with Jews, in Christ (especially in Eph 3:6)' (Soal 2020:69).

The translation of $\mu v \sigma \tau$ in $\rho$ ov as 'sacred secret' contrasts with most English Bible versions that translate it as 'mystery'. 'Mystery' is a transliteration of $\mu v \sigma \tau$ ' $\rho ı v$, not a translation of it. A transliteration is literally 'bringing across the letters' (Schoenheit 2019:1). "The English word "mystery" usually means something that is incomprehensible, beyond understanding and unknowable. In contrast, a "secret" is something that is known by someone but unknown by others' (Soal 2020:69). Thus, $\mu v \sigma \tau$ in better understood as a 'sacred secret', that is, 'a secret in the sacred or spiritual realm that must be made known by God', revealed by God (Schoenheit 2019:1). In the NT (Douglas

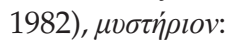

[S]ignifies a secret which is being, or even has been, revealed, which is also divine in scope, and needs to be made known by God to men through his Spirit. (p. 805)

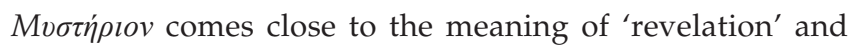
'is a temporary secret, which once revealed is known and understood - a secret no longer' (Douglas 1982:805), 'what is

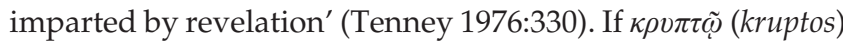
is translated as 'secret' (or secular secret or hidden) and $\mu v \sigma \tau$ '́p communicated clearly and 'we English-speaking people are in a better position to know and understand what God has said in His Word' (Schoenheit 2019:4).
Thus $\mu v \sigma \tau$ pıov (sacred secret or mystery, used interchangably henceforth) 'refers to the revelation that all things brought together in Christ' (Soal 2020:70). The sacred secret of Christ is 'the complete union of Jews and Gentiles with each other through the union of both with Christ' (Stott 1979:117). Specifically, Gentiles and Jews are united in Christ. 'In Christ' is foundational to understand the mystery, for that phrase reflects a double union, namely, 'the union with Christ and the union of Jews and Gentiles in Him' (Soal 2020:70).

\section{The mystery of unity (Eph 3:5)}

The ontology of the believer gives rise to the mystery of unity for believers of diverse cultural backgrounds. NT believers are unique in that they (Soal 2020):

$[H]$ ave experienced the fulfilment of the mystery of God's purposes. Although predicted, the sacred secret was kept hidden for ages (Rm 16:25-26), hidden from generations past (Col 1:26, cf. Eph $3: 5,9,11)$ that it might be revealed to apostles and prophets such as Paul himself and through them to believers (Eph 3:1-12, cf. Pt 1 1:10-12). (p. 70)

Paul describes his calling to reveal the mystery of God to the Gentiles as 'the grace of God given to me for you' (Eph 3:2).

The Biblical idea of a sacred secret reminds diverse humanity that God holds the course of human events in his hands. God has so shaped human events that they work together for the salvation of his people. The sacred secret also 'demonstrates the graciousness of God in revealing his redemptive purposes to prophets and apostles and, through them, to all who are willing to hear' (Thielman 1996:2).

The sacred secret made known to Paul 'by revelation' ( $\kappa \alpha \tau \grave{\alpha}$ $\dot{\alpha} \pi \sigma \kappa \alpha \dot{\lambda} \nu \psi \imath v)$ is contrasted with a gospel 'of human origin' ( $\kappa \alpha \tau \grave{\alpha} \ddot{\alpha} v \theta \rho \omega \pi o v$, Gl 1:11). Ephesians asserts that 'Paul is really a steward rather than an inventor' (Soal 2020:70). The gospel preached by the Apostle is given to him by God, by revelation and he is 'an authoritative interpreter' (Fowl 2012:108).

The assumption is that as the Ephesians read this account of the reconciliation of Jew and Gentile in Christ (in Eph 1-2), and then the Ephesians will perceive Paul's insight into the 'mystery of Christ'. 'This mystery is not a cultivated interpretive skill or as a general discerning disposition' (Soal 2020:71). Rather, this mystery 'is an insight that has been given to Paul as part of his stewardship of God's grace' (Fowl 2012:108).

The insight into the 'mystery of Christ' was not revealed to earlier generations (Eph 3:5). The New International Version (NIV 1984 translation) wording 'men in other generations' (Eph 3:5) is a tenuous translation of an uncommon phrase, as a double plural: 'children [sons] of humans [men]' (cf. Mk $3: 28$, has the only other occurrence of this phrase in the NT) (Snodgrass 1996:161). This raises some questions. Is there no knowledge of this mystery in the OT? 'The syntax of the 
phrase seems to pose an absolute contrast between "other generations" and "now"' (Fowl 2012:109). "This is where the interpreter should attend to the nature of the "mystery" spoken of in Ephesians' (Soal 2020:71).

The focus in Ephesians is on the reconciliation of Gentile and Jew in Christ in the ways outlined in Ephesians 2:11-22. While in Colossians 1:24-29, the 'mystery' is a more general reference to salvation in Christ. The 'inclusion of the Gentiles within the redeemed people of God in Christ... [was not] anticipated in earlier generations' (Fowl 2012:109). OT believers 'had no vision of the church, the assembling together of all the saved into one united Body, in which there were absolutely no racial distinctions' (MacArthur 1986:91). Ephesians 3:5 does not negate that in the OT, Gentiles were considered in God's purposes, 'but no previous revelation focused on the Gentiles being accepted by God on equal footing with Jews' (Snodgrass 1996:161).

The OT foretold that the Christ would come to Gentiles (Is 11:10; 49:6; 54:1-3; 60:1-3). Gentiles would be redeemed by the Messiah (Hs 1:10, Am 9:11ff.), and they will also receive the Holy Spirit (Jl 2:28-29). In spite of these prophesies, the very idea of including Gentiles in one body with Jews (MacArthur 1986):

$[W]$ as the spiritual equivalent of saying that lepers were no longer to be isolated, that they were now perfectly free to intermingle and associate with everyone else as normal members of society. (p. 91)

Historically, Judaism considered their spiritual separation from Gentiles as so unchanging and 'so right that the thought of total equality before God was inconceivable and little short of blasphemy' (MacArthur 1986:92).

Paul clarifies that he was not the only recipient of this revealed mystery (Eph 3:5). Via the Holy Spirit, God has revealed this mystery known to 'his holy apostles and prophets' (Eph 3:5). The earliest direct Divine revelation of this concept would be Peter's vision in Acts 10. Paul is at pains to challenge any thinking that 'the interpretation of God's mystery is idiosyncratic' (Soal 2020:72). This perception of the divine mystery is not unique to Paul.

The primary progressive nature of the revelation is that the Gentiles are now to be on the same footing as the Jews. This is observed in the emphasised in the original text using

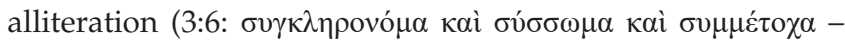
'heirs together, members together of one body, and sharers together'). The historical promises made to Israel were now made to Gentile Christians as 'heirs together with' (cf. Rm 8:17, Pt 1 3:7) the Jewish Christians. The implication is that 'Gentile Christians and Jewish Christians together receive a full share of all benefits' (Soal 2020:72). The NT 'inheritance' language was a way of refering to salvation. Inheritance was either in terms of 'God's inheriting a people or the people's receiving an inheritance from God' (Snodgrass 1996:161).

\section{The purpose of the mystery (Eph 3:6)}

Ephesians 3:6 summarises the purpose of the mystery, that Gentiles become 'fellow heirs, fellow members of the body and fellow participants in the promise in Christ Jesus through the gospel' (Eph 3:6). This sacred secret is 'no longer hidden' (Fowl 2012:110). This mystery should become a basic ingredient of Christian kerygma.

Through acceptance of the Good News, a believer finds that they 'live and move' in Christ (Ac 17:28). The Messiah then recreates among believers an 'absolutely new society' (MacArthur 1986:93). In that new society, true unity may exist in Christ. Christ empowers practical unity in the church to occur when Christians realise and live by the positional unity they already have (O'Brien 1999):

In our present context, however, this variegated wisdom has particular reference to God's richly diverse ways of working which led to a multi-racial, multi-cultural community being united as fellow-members in the body of Christ. (p. 245)

Reconciling race is a regular topic of debate among churhes of the Baptist Union of Southern Africa at their national assemblies (De Jong 2017; Ihlenfeldt 2017). Across the Atlantic (one of the old, tragic slave routes) among Southern Baptists in the United States, debate revolves around whether racial reconciliation is a gospel issue (Williams 2015:1). Among Southern Baptists who affirm that racial reconciliation is a gospel issue, they cite various passages to support this claim (Rm 1:16-17, Gl 2:11-14, Eph 2:11-3:8). Each verse reveals that the Biblical categories of race, otherness and 'racial reconciliation intersect with salvation' and the Good News (Soal 2020:73).

A theology of unity means that Gentile Christians belong and benefit the same as Jewish Christians. 'This unity finds its centre in being in Christ Jesus' (Soal 2020:73). By definition, if geography is identity, then being in Christ makes Jews and Gentiles one. 'In a multicultural community our geographical proximity with one another and in Christ, should unite us' (Soal 2020:73). The kerygma includes highlighting our unity as part of the message. 'Our divisions are no longer as much between Greek and Jew', but contemporary divisions between cultures and divisive individualism are questioned 'by the theology of unity' (Soal 2020:73). 'To be in Christ is to be made one with all who are in him' (Snodgrass 1996:168).

Reconciliation with our Creator should lead to talk of racial reconciliation. Racial reconciliation in evangelical circles starts with 'the gospel's call for churches to be multicultural', where possible (Williams 2015:1). Gospel-centred racial reconciliation results in diverse and multicultural churches. Yet, 'diversity may not be the same as gospel-centred racial reconciliation. The goal of gospel-centred racial reconciliation is not simply diversity' (Soal 2020:73). Gospel-centred racial 
reconciliation seeks to love the 'other'. That care of the 'other' flows (Soal 2020):

[F]rom the Spirit-empowered obedience of those who repent, believe in the death, resurrection of Jesus by faith, and are justified by faith in Jesus Christ, the Jewish Messiah (Ac 2:1-41, Rm 3:21-4:25, Gl 2:11-6:2). (p. 73)

Gospel-centred racial reconciliation may sound 'more like a spiritualised version of Affirmative Action, which is not the same as gospel-centred racial reconciliation' (Williams 2015:3). The purpose of this sacred secret is that God unites what has been separated by history and culture.

\section{The preaching of this mystery (Eph 3:7-9)}

Paul, once the hostile Saul to anyone other than the Hebrews, now preaches to Gentiles as a 'Hebrew of Hebrews' (Phlm 3:5). This sacred secret in 'Ephesians 3 is the clearest statement in the NT of the innovation of his message' (Soal 2020:74). Paul was called not only to proclaim the sacred secret of Christ among the Gentiles but also:

[T] o bring to light what is the administration of the mystery ... in order that the manifold wisdom of God might now be made known through the church. (Eph 3:7)

Hence, he had not only been given insight into the mystery of Christ but also insight into how the mystery is to be applied 'practically by diverse believers united in the local church. This practical Christian life is expanded on from Ephesians 4:1 to $6: 20^{\prime}$ (Soal 2020:74).

Ephesians 2:8 is viewed as 'the very apex of the book from which all else that is written derives its context and meaning' (DeYmaz 2013:2). This sacred secret represents the very substance of Paul's ministry and life. This perspective is supported by his request to the Ephesians to:

$[P]$ ray also for me, that ... words may be given me so that I will fearlessly make known the mystery of the gospel, for which I am an ambassador in chains. Pray that I may declare it fearlessly, as I should. (Eph 6:19-20)

A few commentators critique Paul's self-depreciating declaration that he was 'less than the least of God's people' (Eph 3:8), arguing that the claim is rather 'like false modesty ... artificial and exaggerated' (Lincoln 1990:183; Mitton 1976:125). However, OT precedent may be found in the description of God's instruments in Daniel 4:17. As part of recounting his dream, Nebuchadnezzar states:

The decision is announced by messengers, the holy ones declare the verdict, so that the living may know that the Most High is sovereign over the kingdoms of men and gives them to anyone he wishes and sets over them the lowliest of men. (Dn 4:17, [authors' added emphasis])

The Aramaic translates as 'the basest, worst and despised of human beings'. It is just such people that God sets over 'the kingdom'. This Semitic euphemism affirms God's grace by which he selects the despised of human beings to fulfil purposes of his kingdom. 'Accordingly, in Ephesians 3:8, Paul was not "exaggerating" his self-portrayal in an artificial manner. Paul was simply reportraying his prophetic credentials' (Soal 2020:75). The revelation of the sacred secret of the kingdom came via the 'least and the despised' of humans (cf. Ps 25:14, see also Asumang 2009:16).

Despite Paul's negligible status (Eph 3:8), Paul is to preach the unimaginable riches of Christ to the Gentiles (Fowl 2012):

In identifying Christ's riches as unimaginable, Paul is further emphasising the point that neither he nor anyone else could have reasoned their way to such an understanding of God's purposes. (p. 111)

Rather than reveal the details of the 'plan of the mystery' (Eph 3:9), 'God had hidden this plan from ages past' (Soal 2020:75). This plan has been kept secret 'in God', indicating 'that the hiding was part of God's purpose and not merely the result of human sin or ignorance' (Soal 2020:75). The reference to God as the Creator of all things is designed to refute the mistaken deduction that this plan was a reaction on God's part or a haphazard device (Best 2001:321). This sacred secret is an 'eternal plan and part of the purposes of the One who created all things' (Soal 2020:75). The comprehensive creative power of God ensures that he is able to bring this plan to fruition, despite the rebellion and actions of the powers (Lincoln 1990:185).

\section{The purpose of the mystery for the church (Eph 3:10-11)}

'Through the church the manifold wisdom of God might be made known to the principalities and powers in the heavenly realms' (Eph 3:10), highlights 'the purposes for which Paul has been given this grace to reach the Gentiles' (Soal 2020:75). The Creator created these principalities and powers (Eph 1:21). As with Christ and the church, these principalities and powers are located in the heavenly realms. Yet, they are not completely under Christ's dominion (Eph 1:22). Thus, the Gentile coming into the church as part of one united multicultural church relays a message. 'And this unifying display alerted the rulers and authorities that is the angelic and demonic world that Jesus had indeed won' (Gray 2013:2).

The 'heavenly realms' (Eph 3:10) refers 'not so much to a place as to a spiritual reality - the reality beyond the visible for the fallen human eye' (Soal 2020:75). This concept of the role the church as a witness to the realms in the heavens has no equivalent elsewhere in the NT. Several explanations are possible:

1. The church illustrates God's wisdom to good angels (Pt 1 1:12).

2. The church reveals God's wisdom to evil powers to bring about their repentance, to announce their defeat, or to cause them to marvel.

3. The church teaches God's wisdom to human institutions or structures to transform their actions. 


\section{Some combination of the above (Snodgrass 1996:163).}

The general context in Ephesians of 'the rulers and authorities' refers to evil powers, not good angels, or human institutions. The 'rulers and authorities' (Eph 3:10) may best be understood as the display of God's glory even to his opponents. The defeat of the evil powers in Christological terms is based on the Christ's death and resurrection that has already been preached (Eph 1:19-22, Col 2:15). Yet, the fourth option of a combination remains a consideration, 'as human institutions may fall under demonic authority (Dn 10:13, Eph 6:12) and angelic powers peer down into this great salvation ( $\mathrm{Pt} 1$ 1:12)' (Soal 2020:76).

Thus, the united church may be the motivation by which these powers might be reconciled to their proper relationship to their Creator and the rest of creation. This cosmic reconciliation happens (Fowl 2012):

$[T]$ hrough the church's preaching or its engagements with earthly powers ... the very existence of the gathered body of Jews and Gentiles reconciled to God and each other in Christ makes known the manifold wisdom of God. (p. 112)

Cosmic reconciliation is refered to in the OT (Is 2:1-4; 60:1-7, Ez 37). When Israel is redeemed, the nations will be drawn to God, Israel and each other. The result will be peace as there was in the garden (Gn 1-2). The redemption of Israel is made manifest in word and deed in the church. In the church, Gentiles are reconciled to God and to the renewed Israel of God, as God purposed. Reconciliation in Christ of Jew and Gentile 'may appear attractive enough to compel the powers to return to their proper place' (Fowl 2012:112). Thus, the reconciliation of Gentile and Jew to God and to each 'would have social and even cosmic consequences' (Soal 2020:76).

Even though these powers reside in the heavenly realms, their grasp of the wisdom of God and any reconciliation depends 'on the material presence of communities formed in Ephesus and elsewhere. Multicultural communities thus have cosmic implications' (Soal 2020:76). As believers of the earthly realm, they engage with the powers in the heavenly realms (Eph 1:3). This kind of thinking is not alien to those holding an animist worldview (Hiebert 1985):

The animist worldview includes the middle level of spiritual forces and powers. The Western Greek dichotomistic or secular worldview excludes the 'middle' which is vital for the animist understanding of life and everyday security. (p. 158)

Whether one holds to a tripartite or dipartite worldview, both imply cosmic consequences for 'the reconciliation of Jew and Gentile, black and white, local and foreigner, to God and to each other, in Christ' (Soal 2020:77).

Cosmic consequences may be misunderstood with differing worldviews. While there 'is an argument to be made for an ethical dualism rather than a cosmic dualism' (Soal 2020:77). In expounding on Ephesians 6:10-19, Harold (2013:158) argues that our battle is not so much in the metaphysical or cosmic sense, as a battle between Satan and God. Rather the battle is an ethical battle, 'as the church witnesses to the watching world'. In Cartesian dualism, the cosmos is viewed as a world created by and belonging to God, yet it is under the sway of evil to such an extent that the world is seen as humans in rebellion to God (Soal 2020:77). 'An impression of dualism is unavoidably created by this means, but it is never a metaphysical dualism, only an ethical one' (Guthrie 1981:150). God is not making war on any person, including the Devil. 'There is no metaphysical dualism' (Soal 2020:77). Ephesians 1:21 reveals that everything in the cosmos is placed under the dominion of Christ, since the cross, where he loosed the binding work of Satan (Eph 1:19-20; Harold 2013:160).

The practical and ongoing presence of the multicultural church in the world makes the wisdom of God known to the cosmic powers (Eph 6:10-19). 'This is not a minor part of the church's mission' (Soal 2020:77). The multicultural church is part of God's 'eternal purpose' accomplished in Christ Jesus our Lord (Eph 3:11). 'In the classroom of God's universe, He is the Teacher, the angels are the students, the church is the illustration, and the subject is the manifold wisdom of God' (MacArthur 1986:97).

The 'multifaceted' ( $\pi \circ \lambda v \pi$ oíкı $\lambda \mathrm{o} \varsigma$ ) wisdom refers to that which is many-sided or different in several ways. "This is the only occurrence in the NT, and it has the idea of "most varied," or "(very) many-sided". It alludes to the variegated facets of God's wisdom ...' (Hoehner 2002:461). The cosmic powers peer into God's manifold (multi-coloured, multi-faceted) wisdom revealed through the church. They see Christ 'taking Jew and Gentile, slave and free, male and female', black and white, rich and poor, and transforming them into one spiritual Body in Jesus Christ (MacArthur 1986:97). 'In Ephesus, Paul encountered magicians who burned their books and left their occultic practices (Ac 19:18f)' (Soal 2020:77-78). Now beyond a local sense, the multifaceted wisdom of God is witnessed on a universal scale (Soal 2020):

This multicultural Christian ministry involves a spiritual battle against powers and authorities (Eph 6:12). The kingdom of God is not a matter of words but of power (1 Cor 4:20). (p. 78)

'This battle for multiculturalism is seen not only historically' with homogeneous church growth models, but theologically with the promotion 'of separate development of different races, especially in South Africa' (Soal 2020:78). 'This gives an unparalleled importance to the church' (Snodgrass 1996:164). This importance lies in the move of the Holy Spirit to unite what has for too long been divided by sin (hatred) between cultures, which makes multiculturalism not a passing worldly fashion or politically correct notion (Davis 2003:106).

This suspicion of the 'other' and the fear of other cultures are supernaturally powerful. Therefore, Paul writes from prison, noting that he is imprisoned not simply for the kerygma of the gospel ( $\mathrm{Rm} \mathrm{16:25)}$ but also for proclaiming the mystery of Christ (also in Col 4:2-4); namely, the sacred secret 'that the Gentiles are fellow heirs (together with the Jews) . . . and fellow partakers of the promise in Christ Jesus through the 
Gospel' (Eph 3:6 NASB). The witness of the multicultural church was so crucial that Paul is 'in prison not for generally preaching salvation, but for specifically preaching Gentile inclusion in an otherwise all ethnically Jewish kingdom of God and local church' (DeYmaz 2013:2). The glory of God through the local church so gripped Paul, that eventually, he was imprisoned and martyred (Ac 22:21-22) for planting united 'Jewish and Gentile (multicultural) churches throughout the Greco-Roman world' (Soal 2020:77).

Paul did not go into a Greco-Roman city and plant a church for the Jews and then a church for Gentiles (non-Jews) because it would have been out-of-step with the Gospel he loved, lived and proclaimed. (Gray 2013:1)

'The heterogeneous, multicultural local church stands as a lighthouse in the darkness of evil and fear, illuminating God's plan to a watching cosmos and world' (Soal 2020:78).

\section{The privilege afforded by mystery (Eph 3:12-13)}

The issue is not who has access to God, but the way believers have access to their Creator (Eph 3:12). The original text ( $\dot{\varepsilon} \vee \tilde{\omega}$

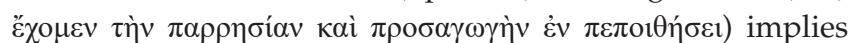
'freedom and unrestricted access to God' (Soal 2020:78). This access involved the confidence that the believer will be welcomed and received' (Soal 2020:78). 'This confidence is by means of faith in Christ or by Christ's faithfulness' (Fowl 2012:113), with both options being theologically tenable and both matching the wider context.

This section concludes in drawing (in Eph 3:12) the two long digressions on God's sacred secret and of Paul's role in proclaiming that mystery, into perspective. Paul's role in the kergyma of the mystery of Christ may be witnessed in Romans. 'In his closing address he' illuminates what is 'prominent in his mind concerning the mystery' of Christ: '... so that all nations might believe and obey him - to the only wise God be glory forever through Jesus Christ! Amen' (Rm 16:25-27); (Soal 2020:79).

\section{Conclusion}

To proclaim the word of God yet fail to elucidate the mystery of Christ is to fail to inform the local church of God's word 'in its fullness' (Col 1:25). 'Gentile inclusion is inextricably linked to the gospel of Paul; and not simply where eternal life is concerned, but also where the local church on earth is concerned' (DeYmaz 2013:2). In Romans (written to another multicultural church), Paul pairs these two concerns (Rm 1:16; 3:21-22, 29-30; 10:9, 11-13; 15:15-16; 16:25-26). In New York City, the fears of some white church members sparked by black refugees protesting injustices led their pastor to say (Piper 2016):

[W] hat seems to be missing among many Christians, is a solid Biblical conviction that ethnic diversity in the church is a beautiful thing, and part of God's ultimate design for his people. (p. 1)
The Ephesian church was probably a house church, a relatively small group by the evaluation of a world that prizes power. Yet, the sacred secret revealed by God to Paul addressed their multicultural character and cosmic effect. Local churches should be 'functional outposts of God's kingdom', and working prototypes of God's new-earth community, and a lighthouse to the cosmic powers (Snodgrass 1996:174). A sense of the importance of the church as the place where the purposes of God are lived out is crucial. The beauty of people from many cultures practically living as one reflects the unity of the Triune God-head - an answer to Christ's prayer (Jn 17:23). The endeavour to guide churches to journey from homogeneous local churches to the promised land of light reflecting multicultural churches has cosmic implications.

\section{Acknowledgements}

This work acknowledges the advice of the author's doctoral supervisors, Dr D. Henry and Dr W.I. Ferreira.

\section{Competing interests}

The authors declare that they have no financial or personal relationships that may have inappropriately influenced them in writing this article.

\section{Authors' contributions}

A.D.S. researched and wrote the article under the supervision of Dr D.H. for his PhD thesis.

\section{Ethical considerations}

This article followed all ethical standards for research without direct contact with human or animal subjects.

\section{Funding information}

This research received no specific grant from any funding agency in the public, commercial or not-for-profit sectors.

\section{Data availability}

Data sharing is not applicable to this article as no new data were created or analysed in this study.

\section{Disclaimer}

The views and opinions expressed in this article are those of the authors and do not necessarily reflect the official policy or position of any affiliated agency of the authors.

\section{References}

Amodio, D.M., Jost, J.T., Master, S.L. \& Yee, C.M., 2007, ‘Neurocognitive correlates of liberalism and conservatism', Nature Neuroscience 10(10), 1246-1247. https:// doi.org/10.1038/nn1979

Asumang, A., 2009, 'Vehicles of divine mystery: Paul's Danielic self-understanding in Ephesians 3', Conspectus, p. 7, viewed 28 October 2019, from https://www. academia.edu/1039791/Vehicles_of_Divine_Mystery_Pauls_Danielic_SelfUnderstanding_in_Ephesians_3. 
Barth, M., 1974, Ephesians, Volumes 34 and $34 \mathrm{~A}$ of the Anchor Bible, Doubleday, Garden City, NY.

Best, E., 2001, Ephesians, T\&T Clark, Edinburgh.

Brown, R., 1958, 'Pre-Christian semitic concept of mystery', Catholic Biblical Quarterly 20(4), 417-433.

Coffman, J.B., 1976, The mystery of redemption, Firm Foundation Publishing House, Austin, TX.

Coffman, J.B., 1999, Ephesians - Coffman's commentary of the New Testament viewed 28 October 2019, from http://classic.studylight.org/com/bcc/view. viewed 28 October 2019,
cgi?book=eph\&chapter $=003$.

Davis, K.L., 2003, 'Building a biblical theology of ethnicity for global mission', The Journal of Ministry \& Theology 7.2, 91-126.

De Jong, C., 2017, 'The challenges to the multicultural church', Baptist Today 3, pp. 8-9.

DeYmaz, M., 2013, Understanding the mystery of Christ, viewed 25 October 2019, from https://www.christianpost.com/news/understanding-the-mystery-of-christ.html.

Douglas, J.D., 1982, New Bible dictionary, InterVarsity Press, Leicester.

Foulkes, F., 1963, The epistles of Paul to the Ephesians, Eerdmans, Grand Rapids, MI.

Fowl, S.E., 2012, Ephesians: A commentary, 1st edn., in C.C. Black, M.E. Boring \& J.T. Carroll (eds.), Westminster John Knox Press, Louisville, KY.

Gallagher, T., 2001, 'The value orientations method: A tool to help understand cultural differences', Journal of Extension 39(6), 165-177, viewed 18 February 2019, from https://archives.joe.org/joe/2001december/tt1.php.

Gray, D., 2013, 8 reasons why the Apostle Paul wants churches to be multi-ethnic, viewed 28 October 2019, from https://ministrytodaymag.com/life/multicultural/20554-8reasons-why-the-apostle-paul-would-want-churches-to-be-multi-ethnic.

Guthrie, D., 1981, New Testament theology, InterVarsity Press, Leicester.

Hampden-Turner, C. \& Trompenaars, F., 2000, Building cross-cultural competence, Wiley, Chichester.

Harold, G., 2013, 'Metaphysical dualism and spiritual warfare: A reading of Ephesians 6:10-19', The South African Baptist Journal of Theology 22, 154-162.

Hiebert, P.G., 1985, Anthropological insights for missionaries, Baker, Grand Rapids, MI.

Hoehner, H.W., 2002, Ephesians: An exegetical commentary, Baker Academic, Grand Rapids, MI.

Howard, F.D., 1979, An introduction to Ephesians, viewed 04 November 2019, from $\mathrm{http}: / /$ preachingsource.com/journal/an-introduction-to-ephesians/.

Ihlenfeldt, R., 2017, 'Growing multicultural churches: The cost of resisting change', Baptist Today, 01 April, pp. 20-12.

Lincoln, A.T., 1990, Ephesians: WBC 42, Word, Waco, TX.

Lipscomb, D., 1939, New Testament commentaries: Ephesians, Gospel Advocate Co., Nashville, TN.

Livermore, D.A., 2009, Cultural intelligence: Improving your CQ to engage our multicultural world, Baker Academic, Grand Rapids, MI.

MacArthur, Jr. J.F., 1986, Ephesians, Moody Press, Chicago, IL.
Martin, R.P., 1991, Ephesians, Colossians and Philemon, Knox Press, Louisville, KY. Mickelson, A.B.,1963, Interpreting the Bible, Eerdmans, Grand Rapids, MI.

Mitton, C., 1976, Ephesians, Olympiants, London.

O'Brien, P.T., 1999, The letter to the Ephesians, Eerdmans, Leicester.

Padilla, C.R., 1992, 'The unity of the church and the homogeneous unit principle', International Bulletin of Missionary Research 6(1), 24-30. https://doi. org/10.1177/239693938200600107

Pickett, M., 2015, 'Caste-sensitive church planting: Revisiting the homogeneous unit principle', Transformation 32(3), 177-187. https://doi.org/10.1177/ 0265378814537763

Pilkington, C. \& Pretorius, L., 2015, 'A conceptual model of the research methodology domain: With a focus on computing fields of study', in 7th International joint conference on knowledge discovery, knowledge engineering and knowledge management (IC3K 2015), 2(Ic3k), pp. 96-107, SCITEPRESS, Lisbon.

Piper, J., 2016, Why Christians love diversity, viewed 10 November 2019, from https:// www.desiringgod.org/articles/why-christians-love-diversity.

Plueddemann, J., 1995, 'Measurable objectives, no! vision, yes!', Evangelical Missions Quarterly 31(2), 184-187.

Schoenheit, J., 2019, Mystery or sacred secret, viewed 04 November 2019, from https://www.truthortradition.com/articles/mystery-or-sacred-secret.

Silva, M., 1986, 'The place of historical reconstruction in New Testament criticism', in D. Carson \& J. Woodridge (eds.), Hermeneutics, authority and canon, pp. 105-134, Zondervan, Grand Rapids, MI.

Snodgrass, K., 1996, NIV application commentary, NT: Ephesians, Zondervan, Grand Rapids, MI.

Soal, A.D., 2020, Guiding Baptist union churches towards multiculturalism: Developing a multicultural tool for globalising urban South Africa, viewed 22 February 2021 , from oai:repository.nwu.ac.za:10394/36406.

Soal, A.D. \& Henry, D., 2018, 'The reversal of Babel: Questioning the early church's understanding of the gift of the holy spirit in Acts as a reversal of the curse of Babel', Verbum et Ecclesia 39(1a), 1842. https://doi.org/10.4102/ve.v39i1.1842

Stott, J.R.W., 1978, 'LOP 1 - The Pasadena consultation: Homogeneous unit principle', Lausanne committee for world evangelization, pp. 1-14, viewed 25 October 2019, from http://www.lausanne.org/content/lop/lop-1.

Stott, J.R.W., 1979, The message of Ephesians, InterVarsity Press, Leicester.

Strong, J., 2001, The new strong's expanded dictionary of Bible words, Thomas Nelson Publisher, Nashville, TN.

Tenney, M., 1976, The Zondervan pictorial encyclopedia of the Bible, Regency Reference Library, Grand Rapids, MI.

Thielman, F., 1996, Mystery, viewed 31 October 2019, from https://www.studylight. org/dictionaries/bed/m/mystery.html.

Wiersbe, W., 1989, Bible exposition commentary, Victor, Wheaton, IL.

Williams, J., 2015, Southern Baptists, race and the gospel, viewed 04 November 2019, from https://thewitnessbcc.com/southern-baptists-race-and-the-gospel/. 